\title{
Design of Multi Robots Based on Single Master Commands
}

\author{
Jasmin.M, Ramya.S, Hemalatha.B.
}

\begin{abstract}
In any type of communication in robots one too many communication is only possible. I.e. One master node can communicate with one slave node only. But here we are going to build up to two slave robots that communicate with the master node. This is possible only by using signee as it is alone having a separate unique id for it. Here we have used only two slave robots for one master node but, we can add a number of robots for the master node having of different id's using of ZigBee transfer protocol.
\end{abstract}

Keywords :: Robots,Commands,Master.

\section{I.INTRODUCTION}

Robots play a vital role in man's life. Nowadays the concept of robots is applied in many places such as military, hospitals, teaching, guarding, etc. The main purpose of introducing robots is to help the man on all occasions and to minimize the work. Faster work progress to mankind. Robots are often used to conduct a variety of tasks which, in certain instances, are hazardous to humans. Robot aid has always been useful to human existence. A robot can bring our things and precede us to different locations. There are several benefits of having automatons in human lives.It can also be used in civil and industrial applications that the robot able to track. These type of robots can minimize the work one can perform many tasks.[1-10]

\section{II.EMBEDDED SYSTEM:}

The overall meaning of an optimizing compiler is that built-in systems are computing systems with tightly coupled hardware and software assimilation intended to conduct a specialized purpose. In some cases, an embedded system can operate as a downloadable system.[11-15]

One class of integrated system components focuses on size, throughput and cost, thus some integrated devices are restricted in capacity, i.e. the device is great for other classes of apps.

Actual-time structures are described as systems wherein the general precision of the scheme relies on both responsive

Revised Manuscript Received on August 22, 2019.

Jasmin.M Assistant Professor, Department of Electronics And Communication Engineering,, Bharath Institute of Higher Education and Research, Chennai,India. rifriz@gmail.com

Ramya.S, Assistant Professor, Department of Electronics And Communication Engineering,, Bharath Institute of Higher Education and Research, Chennai .India. ramyasamdra@gmail.com

Hemalatha.B, Assistant Professor, Department of Electronics And Communication Engineering,, Bharath Institute of Higher Education and Research, Chennai,India. contacthemab@gmail.com rightness and timing expediency. Timing reliability is at least as essential as workable absolutism.

There are several types of embedded systems are there they are categorized as 1. Standalone Embedded system, 2. Networking Embedded system. Washing machines come under standalone embedded systems. Network printer comes under network embedded systems.

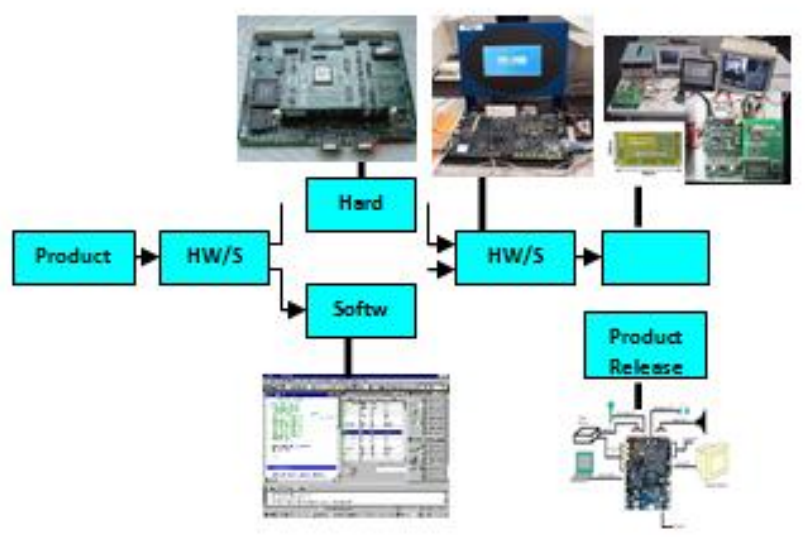

The above diagram shows the life cycle of the development of the Embedded systems.

\section{III.BACKGROUND:}

In the existing system, the robots are designed as one to one communication. That is one master and one slave communication. The master cannot connect more than one slave in a single time. One to one communication.More time consumption. Cannot perform multi-level works. It is Not user-friendly. In the proposed system we are designing the robots which can connect multi-level communications. That is here only one master node and remaining we can have $\mathrm{N}$ number of slaves.

This is possible only by using ZigBee which is the only device having a unique ID. One to many communication .Can perform multi-tasking. Less time consumption. User-friendly. This article offers a new visual service command using a non-vector space control theory, which enables the system to customize its required human-following variables as the required picture gained from self-driven protests. The method provides a convenient and responsive way for humans to customize mobile robots to perform human-following tasks in the way that humans chose.

To run through the fences, the robot computes the position and range to the fences identified. This article defines the above-mentioned technique and analyses some exploratory outcomes of running across the 


\section{Design of Multi Robots Based on Single Master Commands}

fences and pass through multiple junctions.

Robot motion can be produced by means of the current performance video clips shown by a human actor. Limited adjustments for robot motion can be produced instantly when the changes are produced by the efficiency director. To accomplish these two goals, we first embraced Open Pose to extract human joint positions from a video clip of information processing.

\section{IV.SOFTWARE DESCRIPTION:}

The software tools which are used for the implementation are listed below, they are

- MPLAB IDE

- C18 COMPILER

\section{V.MP LAB:}

MPLAB The integrated scripting language is a extensive editor, business analyst and model desktop for the production of encoded structure using Bar code PIC MCU and PIC DSC.MPLAB is a screen operating system simple tool that operates on a PC to create a microchip circuit board and transceiver processor application. It is called an embedded production atmosphere or an IDE, it provides a single interconnected society for the development of an encapsulated microcontroller code..

\section{VI.C18 COMPILER:}

The MPLAB C18 compiler is a stand-alone, optimized ANSI $\mathrm{C}$ constructor for the PIC single board system. The constructor differs from the ANSI ideal X3.159-1989 only where the conventional conflicts with the effective assistance of the PIC micro MCU are present. The compiler is a 32-bit Linux console implementation and is fully compliant with the Microchip MPLAB IDE, enabling secure level linting with the MPLAB ICE in the circuit emulator, the MPLAB ICD 2 in the circuit preprocessor or the MPLAB SIM simulator.

\section{VII.TRANSMITTER SECTION:}

The Microcontroller is the main part of the system which can control any part of the system. It is connected with a ZigBee module to receive data.

The Battery is connected to the Arduino of the microcontroller. Micro-controller is the main part of the system which can control any part of the system. It is connected with a Zigbee module to receive data. The Battery is connected to the Arduino of the microcontroller.

The Microcontroller is the main part of the system which can control any part of the system. It is connected with a ZigBee module to receive data.

The Battery is connected to the Arduino of the microcontroller. Micro-controller is the main part of the system which can control any part of the system. It is connected with a Zigbee module to receive data. The Battery is connected to the Arduino of the microcontroller.

\section{VIII.RECEIVER SECTION:}

It is having two sections transmitter and receiver section. Robots are designed as per the circuit diagram. Both the section is connected by the means of Zigbee protocol. Whatever the command given by the transmitter will be received by the receiver robots and according to the commands received it will start performing.

\section{IX.COMPONENTS:}

HARDWARE USED-

1.Zigbee

2.Arduino microcontroller

3.Dc gear motor

4.Motor driver

5.Battery

6.I2C

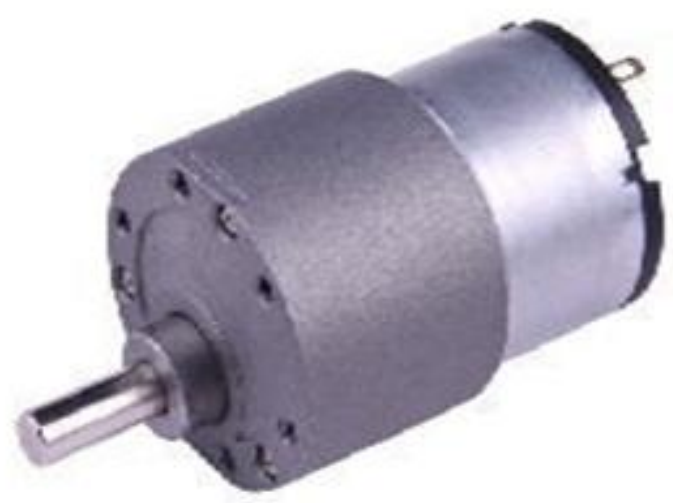

\section{X.SOFTWARE USED-}

1.Proteus IDE

2.Arduino IDE

3.Embedded C

4.Java.

battery:

Specifications

$12 \mathrm{~V} 1.3 \mathrm{Ah}$ sealed the lead acid battery

1. CE and RoHS

2. 2. Good quality and dependability 3. It's a repairs-free, charging dock.

3. And continues long life cycle process replaceable

4. $12 \mathrm{~V} 1.3 \mathrm{Ah}$ sealed the lead-acid battery

General Features: Sealed and maintenance free operation. Non-Spill-able construction design.ABS containers and covers(UL94HB, UL94- 0)optional.Safety valve installation for explosion proof. High quality and high reliability. Exceptional deep discharger ecovery performance.Low self-discharge.

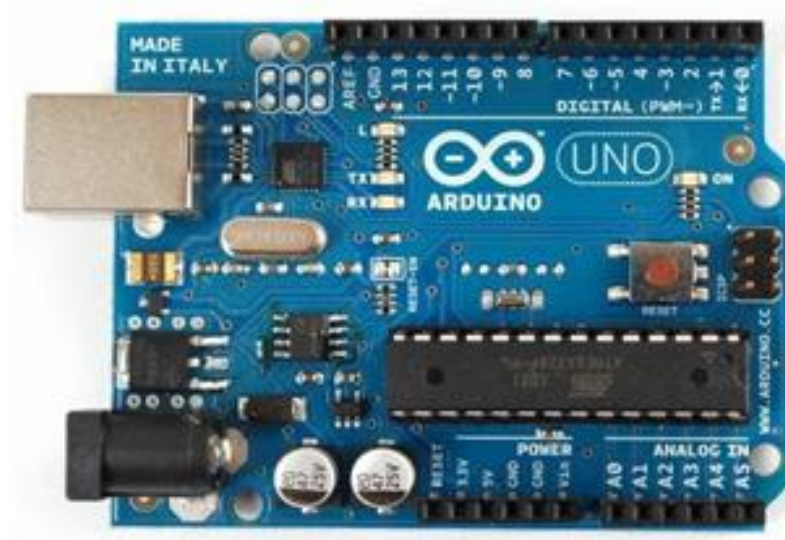




\section{XI.DC GEAR MOTOR:}

The equipment engine has 60 rotations per minute. It's a $12 \mathrm{~V}$ DC motor with a steel belt. It has a length of $6 \mathrm{~nm}$ shaft. The size of the gearbox is $37 \mathrm{~mm}$ and the diameter of the engine is $28.5 \mathrm{~mm}$ with a duration of $63 \mathrm{~mm}$ with out a screw. The size of the engine hose is $15 \mathrm{~mm}$ and the strength is $300 \mathrm{gm}$. It has a peak power of about $38 \mathrm{~kg} \mathrm{~cm} \mathrm{No-load}$ current $=800 \mathrm{~mA}(\max )$, Load current $=$ up to $9.5 \mathrm{~A}(\max )$.

\section{XII.MICROCONTROLLER:}

Microcontroller boards designs use a variety of projects. The boars equipped with a set of digital and analog $\mathrm{i} / \mathrm{p}$ and $\mathrm{o} / \mathrm{p}$ pins that may be interfaced into various expansions boards or breadboards and other circuits. The boards feature serial communication interfaces, using USB in some models which are also used for some programs from personal computers the microcontrollers are typically programmed using a dialect of features from the programming languages $\mathrm{C}$ and $\mathrm{C}++$.

The microcontroller here we used is 32 bit and having of $512 \mathrm{~kb}$ of memory. We can give up to $12 \mathrm{v}$ for this Arduino.

\section{XIII.APPLICATIONS}

These type of robots thoroughly is used in various industries. For example, we can say that hospitals, Giving commands to the auto level checking of different patients by using the commands of the master robot.In military purposes, we can use them as security agents for border checking purposes if an enemy crosses the border. We can put a number of Sensors for the Robots like sensing, CCTV, Ultrasonic sensor etc.Here in this we no need strain to command every robot in different places around the border, we can simply give commands to the master robot thereby it can control other robots by Zigbee transfer protocol. Each robot is having a different unique id for the data transmission from the emitter end to receiver end. But here the main drawbacks we are using Zigbee transfer protocol it can only communicate through shorter distances. We can implement much more for this. Say, communication between the slave robots that can reduce much more strain for the master robot. If one of the robot's battery is drained it will send the information to the other robot. Then it can come and replace the battery of the other robot. We can add a number of applications for this project By simply coding to the required software for the microcontroller.[16-20]

\section{XIV.DISCUSSION \& CONCLUSION}

It is very satisfying to execute this project and see how it works. The requirements are fulfilled and the objectives were accomplished. As a result, a cellular Zigbee regulated robot has been intended which can be used as anticipated for many apps. The scheme has created a multipurpose machine centered on Zigbee and then using the Arduino microprocessor. In order to reinforce safety and protection in any large nation, We urgently need a scanner scheme to block our missile system. Therefore, in order to create this world a lovely place to reside, we strongly need a robot to help us in our endeavors. With the development of this scheme, we would have a renaissance in defense and security apps that will create change as the Industrial Revolution once did.

\section{REFERENCES}

1. Kongkham, D. \& Sundararajan, M. 2019, "Distributed wideband sensing method for faded dynamic spectrum access", International Journal of Innovative Technology and Exploring Engineering, vol. 8, no. 10, pp 4309-4312.

2. Balaji, S., John Paul Praveen, A. \& Mohanraj, R. 2019, "Recognizable proof and analysis of palm print in biometric authentication system using bayes techniques", International Journal of Innovative Technology and Exploring Engineering, vol. 8, no. 9 Special Issue 3, pp. 1126-1129.

3. Kavitha, G., Priya, N., Velvizhi, R. \& Allin Geo, A.V. 2019, "Parallel computation in correspondence and signal processing", International Journal of Innovative Technology and Exploring Engineering, vol. 8, no. 9 Special Issue 3, pp. 1136-1139.

4. Hema, R., Sundararajan, M. \& Balaji, S. 2019, "Smartphone control robot with automatic firing gun", International Journal of Innovative Technology and Exploring Engineering, vol. 8, no. 9 Special Issue 3, pp. 625-627.

5. Kaliyamurthie, K.P., Sundar Raj, B., Velvizhi, R. \& Shanmugapriya, K 2019, "Dual band paper substrate CPW antenna for wireless applications", International Journal of Innovative Technology and Exploring Engineering, vol. 8, no. 9 Special Issue 3, pp. 605-608.

6. Geo, A.V.A., Arunachalam, A.R., Michael, G. \& Elankavi, R. 2019, "Evaluating architecture using compact modalities", International Journal of Innovative Technology and Exploring Engineering, vol. 8, no. 9 Special Issue 3, pp. 836-838.

7. Theivasigamani, S., Jeyapriya, D. \& Anita Davamani, K. 2019 , "Anamoly analyzing and exploring for wireless sensor networks", International Journal of Innovative Technology and Exploring Engineering, vol. 8, no. 9 Special Issue 3, pp. 1116-1118.

8. Jeyapriya, D., Theivasigamani, S., Velvizhi, R. \& Nandhini, P. 2019, "Program detection in wireless feeler networks", International Journal of Innovative Technology and Exploring Engineering, vol. 8, no. 9 Special Issue 3, pp. 1194-1195.

9. Gowri Sankaran, B., Karthik, B. \& Vijayaragavan, S.P. 2019, "Image compression utilizing wavelet transform", International Journal of Innovative Technology and Exploring Engineering, vol. 8, no. 10, pp. 4305-4308.

10. Gowri Sankaran, B., Karthik, B. \& Vijayaragavan, S.P. 2019, "Weight ward change region plummeting change for square based image huffman coding", International Journal of Innovative Technology and Exploring Engineering, vol. 8, no. 10, pp. 4313-4316.

11. Hema, R., Sundararajan, M. \& Balaji, S. 2019, "Smartphone control robot with automatic firing gun", International Journal of Innovative Technology and Exploring Engineering, vol. 8, no. 9 Special Issue 3, pp. 625-627.

12. Rangaswamy, K. \& Rajabhushanam, C. 2019, "Congestion control in wireless network using TCP friendly rate control (TFRC)", International Journal of Recent Technology and Engineering, vol. 8, no. 2 Special issue 3, pp. 1598-1602.

13. Tamil Selvan, S. \& Sundararajan, M. 2019, "Performance Parameters of 3 Value 8t Cntfet Based Sram Cell Design Using H-Spice", International Journal of Recent Technology and Engineering, vol. 8, no. 2 Special issue 5, pp. 22-27.

14. Vinoth, V.V. \& Kanniga, E. 2019, "Steganographical techniques in hiding text images - system", International Journal of Recent Technology and Engineering, vol. 8, no. 2, pp. 6535-6537.

15. Saravana, S., Balaji, S., Arulselvi, S. \& John Paul Praveen, A. 2019 "Reliable power quality monitoring and protection system", International Journal of Innovative Technology and Exploring Engineering, vol. 8, no. 9 Special Issue 3, pp. 644-645.

16. Sundaramoorthy, A. \& John Wiselin, M.C. 2019, "Single patch antenna with multiple feed", International Journal of Innovative Technology and Exploring Engineering, vol. 8, no. 9, pp. 1743-1747.

17. Velavan, R., Bharanidharan, S. \& Sheeba, B. 2019, "EMF pollution Causes, effects and protection", International Journal of Innovative Technology and Exploring Engineering, vol. 8, no. 9 Special Issue 3, pp. 1166-1168.

18. Veer, R.A., Arulselvi, S. \& Karthik, B. 2019, "Construction of ensemble square classification approaches in MIMO OFDM", International Journal of Engineering and Advanced Technology, vol. 8, no. 5, pp. 2039-2041.

19. Agitha, W. \& Kaliyamurthie, K.P. 2019, "Improved energy efficient in WBAN using MAC with cloud computing", International Journal of Innovative Technology and Exploring Engineering, vol. 8, no. 8, pp. 2405-2408.

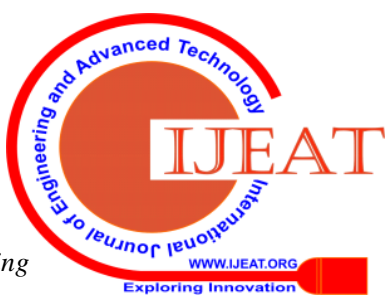


20. Kastro, G.G. \& Wiselin, M.C.J. 2019, "Design and analysis of stub loaded resonator", International Journal of Recent Technology and Engineering, vol. 8, no. 1 Special Issue4, pp. 272-283.

\section{AUTHORS PROFILE}

Jasmin.M Assistant Professor, Department of Electronics And Communication Engineering,, Bharath Institute of Higher Education and Research, Chennai,India.

Ramya.S, Assistant Professor, Department of Electronics And Communication Engineering,, Bharath Institute of Higher Education and Research, Chennai .India.

Hemalatha.B, Assistant Professor, Department of Electronics And Communication Engineering,, Bharath Institute of Higher Education and Research, Chennai,India. 